\title{
Consequences of the multipatient use of a single- patient capillary blood sampling device (CBSD)
}

\author{
P Staeger ${ }^{1}$, F Ninane ${ }^{1}$, L Mazzolai ${ }^{1}$, D Moradpour ${ }^{1}$, J Wasserfallen ${ }^{1}$, E Masserey ${ }^{2}$, L Senn ${ }^{1}$, G Zanetti ${ }^{*}$ \\ From International Conference on Prevention \& Infection Control (ICPIC 2011) \\ Geneva, Switzerland. 29 June - 2 July 2011
}

\section{Introduction / objectives}

Multipatient use of a single-patient CBSD occurred in an outpatient clinic during 4 to 16 months before its notification. We looked for transmission of blood-borne pathogens among exposed patients.

\section{Methods}

Exposed patients underwent serology testing for HBV, $\mathrm{HCV}$ and HIV. Patients with isolated anti-HBc received one dose of hepatitis B vaccine to look for a memory immune response. Possible transmissions were investigated by mapping visits and sequencing of the viral genome if needed.

\section{Results}

Of 280 exposed patients, 9 had died without suspicion of blood-borne infection, 3 could not be tested, and 5 declined investigations. Among the 263 (93\%) tested patients, $218(83 \%)$ had negative results. We confirmed a known history of HCV infection in 6 patients $(1 \mathrm{co}-$ infected by HIV), and also identified resolved HBV infection in 37 patients, of whom 18 were already known. 2 patients were found to have a previously unknown $\mathrm{HCV}$ infection. According to the time elapsed from the closest previous visit of a HCV-infected potential source patient, we could rule out nosocomial transmission in one case (14 weeks) but not in the other (1 day). In the latter, however, transmission was deemed very unlikely by 2 reference centers based on the sequences of the E1 and HVR1 regions of the virus.

\section{Conclusion}

We did not identify any transmission of blood-borne pathogens in 263 patients exposed to a single-patient CBSD, despite the presence of potential source cases.

${ }^{1}$ University Hospital, Lausanne, Switzerland

Full list of author information is available at the end of the article
Change of needle and disinfection of the device between patients may have contributed to this outcome. Although we cannot exclude transmission of HBV, previous acquisition in endemic countries is a more likely explanation in this multi-national population.

\section{Disclosure of interest}

None declared.

\section{Author details}

${ }^{1}$ University Hospital, Lausanne, Switzerland. ${ }^{2}$ Service of Public Health, Lausanne, Switzerland.

Published: 29 June 2011

doi:10.1186/1753-6561-5-S6-P92

Cite this article as: Staeger et al:: Consequences of the multipatient use of a single-patient capillary blood sampling device (CBSD). BMC Proceedings 2011 5(Suppl 6):P92.

Submit your next manuscript to BioMed Central and take full advantage of:

- Convenient online submission

- Thorough peer review

- No space constraints or color figure charges

- Immediate publication on acceptance

- Inclusion in PubMed, CAS, Scopus and Google Scholar

- Research which is freely available for redistribution

Submit your manuscript at www.biomedcentral.com/submit 